\title{
HTLV-1 Tax-induced NF- $\kappa$ B activation is negatively regulated by Ubiquitin-specific peptidase 20 (USP20)
}

Junichiro Yasunaga ${ }^{*}$, Frank C Lin ${ }^{1}$, Xiongbin Lu², Kuan-Teh Jeang ${ }^{1}$

From 15th International Conference on Human Retroviruses: HTLV and Related Viruses

Leuven and Gembloux, Belgium. 5-8 June 2011

Human T cell leukemia virus type 1 (HTLV-1) causes a fatal hematopoietic malignancy, adult $\mathrm{T}$ cell leukemia (ATL), and a viral oncoprotein Tax is considered to play the important roles in leukemogenesis through its potent activation of NF- $\kappa$ B. Protein ubiquitination is crucial for the proper regulation of NF- $\kappa \mathrm{B}$ pathway. It is also known that the function of Tax is modified by ubiquitination, indicating that ubiquitination machineries contribute to the oncogenic mechanisms of ATL. We report that two ubiquitin-specific peptidases, USP20 and USP33, deubiquitinate TRAF6 and suppress IL- $1 \beta$-induced NF- $\kappa$ B activation. We find that USP20 deubiquitinates Tax and inhibits Tax-induced NF- $\kappa$ B activation, consistent with Tax being a substrate of USP20. In HTLV-1-transformed cells, the transcription of USP20 is reduced compared with HTLV-1-negative T cells, and ectopic USP20 expression was found to inhibit the proliferation of an HTLV-1-transformed cell line, MT4. Our findings suggest USP20 is a key negative regulator of NF- $\kappa$ B signaling and can influence HTLV-1-induced leukemogenesis.

\section{Author details}

${ }^{1}$ Molecular Virology Section, Laboratory of Molecular Microbiology, NIAID, $\mathrm{NIH}$, Bethesda, Maryland, 20892, USA. ${ }^{2}$ University of Texas MD Anderson Cancer Center, Houston, TX, 77030, USA.

Published: 6 June 2011

doi:10.1186/1742-4690-8-S1-A129

Cite this article as: Yasunaga et al: HTLV-1 Tax-induced NF- $\kappa$ B activation is negatively regulated by Ubiquitin-specific peptidase 20 (USP20).

Retrovirology 2011 8(Suppl 1):A129.

\footnotetext{
* Correspondence: jyasunag@virus.kyoto-u.ac.jp

${ }^{1}$ Molecular Virology Section, Laboratory of Molecular Microbiology, NIAID,

$\mathrm{NIH}$, Bethesda, Maryland, 20892, USA

Full list of author information is available at the end of the article
}

Submit your next manuscript to BioMed Central and take full advantage of:

- Convenient online submission

- Thorough peer review

- No space constraints or color figure charges

- Immediate publication on acceptance

- Inclusion in PubMed, CAS, Scopus and Google Scholar

- Research which is freely available for redistribution

Submit your manuscript at www.biomedcentral.com/submit

\section{() Biomed Central}

\section{() Biomed Central}

(C) 2011 Yasunaga et al; licensee BioMed Central Ltd. This is an open access article distributed under the terms of the Creative Commons Attribution License (http://creativecommons.org/licenses/by/2.0), which permits unrestricted use, distribution, and reproduction in any medium, provided the original work is properly cited. 